Pace University

DigitalCommons@Pace

$5-2020$

\title{
Arbitration Archetypes for Enhancing Access to Justice
}

Jill I. Gross

Elisabeth Haub School of Law at Pace University

Follow this and additional works at: https://digitalcommons.pace.edu/lawfaculty

Part of the Dispute Resolution and Arbitration Commons

\section{Recommended Citation}

Jill I. Gross, Arbitration Archetypes for Enhancing Access to Justice, 88 Fordham L. Rev. 2319 (2020), https://digitalcommons.pace.edu/lawfaculty/1160/.

This Article is brought to you for free and open access by the School of Law at DigitalCommons@Pace. It has been accepted for inclusion in Pace Law Faculty Publications by an authorized administrator of DigitalCommons@Pace. For more information, please contact dheller2@law.pace.edu. 


\title{
ARBITRATION ARCHETYPES FOR ENHANCING ACCESS TO JUSTICE
}

\author{
Jill I. Gross*
}

In the second half of the twentieth century, the use of arbitration proliferated in the United States as part of a greater alternative dispute resolution (ADR) movement, with the promise that using ADR processes would, among other things, enhance disputants' access to justice. Arbitration offers disputing parties a process to resolve their dispute, which, at least in theory, is known for decreased cost, increased speed, party control, privacy, and finality. These characteristics generally enhance parties' access to justice because, as compared to litigation, barriers to entry are lower, outcomes are delivered more quickly, substantive outcomes are more equitable, and parties have a greater opportunity to be heard. However, not all twenty-first-century arbitration proceedings share these characteristics. Rather, today, arbitration comes in many forms and can be administered by different forums and procedural rules with a great variation in how cheap, how fast, and how procedurally and substantively fair the process really is. Whether a particular form of arbitration enhances access to justice depends greatly on the characteristics of the process in a particular forum or industry. This Article offers a simple framework to determine which types of arbitration truly enhance access to justice and which types do not. The Article also aims to identify a few "arbitration archetypes" that are more likely to support the claim that arbitration enhances parties' access to justice.

\section{INTRODUCTION}

It is true that both employment arbitration and labor arbitration are called "arbitration." But just as hounds and greyhounds, mongrels and spaniels are all called dogs, they're not the same animal. ${ }^{1}$

\footnotetext{
* Associate Dean for Academic Affairs and Professor of Law, Elisabeth Haub School of Law at Pace University. This Article was prepared for the Symposium entitled Achieving Access to Justice Through ADR: Fact or Fiction?, hosted by the Fordham Law Review, Fordham Law School's Conflict Resolution and ADR Program, and the National Center for Access to Justice on November 1, 2019, at Fordham University School of Law. I am grateful for the valuable research assistance of Kaitlyn Greiner, J.D. Candidate, 2020, Elisabeth Haub School of Law at Pace University.
}

1. Brief Amicus Curiae for the National Academy of Arbitrators in Support of Respondents at 16, 14 Penn Plaza LLC v. Pyett, 556 U.S. 247 (2009) (No. 07-581), 2008 WL 2608109 , at *16 (citation omitted) (citing WILlLAM SHAKESPEARE, MACBETH act 3, sc. 1). 
Arbitration, a dispute resolution process where parties agree to submit their dispute to third-party neutrals who, after hearing from all parties, issue a binding decision or award, ${ }^{2}$ has been used to resolve commercial disputes in the United States since the country's founding. ${ }^{3}$ Participants choose arbitration, at least theoretically, because they consider it to be a speedy and inexpensive form of dispute resolution as compared to litigation, as it uses streamlined procedures to reach an outcome based on principles of law, equity, custom, and practices unique to a particular industry. ${ }^{4}$ Arbitrators derive their power to decide the parties' disputes entirely from the parties' consent to trade formal, court-based adjudication for a process promising efficiency and equity. 5

The use of commercial arbitration in the United States exploded across a wide variety of industries in the latter half of the twentieth century due primarily to two forces: first, the U.S. Supreme Court's broad interpretation of the Federal Arbitration Act 6 (FAA) to declare that predispute arbitration agreements are rigorously enforced ${ }^{7}$ and, second, the rise of the alternative dispute resolution (ADR) movement as a means to enhance access to justice. For the first, companies learned that they could insert predispute arbitration clauses in their business-to-business (B2B) contracts and in their adhesive consumer, franchise, and employment contracts, and courts would enforce them against virtually any challenge. 8 For the second, at least in the B2B context, commercial parties agreed with the narrative that arbitration offered a less costly and more equitable alternative to the slow and expensive civil litigation process. ${ }^{9}$ These procedural advantages raised hopes that the

2. See Imre Szalai, Outsourcing Justice: The Rise of Modern Arbitration LaWs IN AMERICA 7 (2013); see also Thomas J. Stipanowich, The Arbitration Penumbra: Arbitration Law and the Rapidly Changing Landscape of Dispute Resolution, 8 NEV. L.J. 427, $435-36(2007)$

3. For a comprehensive history on the use of arbitration to resolve commercial disputes in England and the United States, see Katherine Van Wezel Stone, Rustic Justice: Community and Coercion Under the Federal Arbitration Act, 77 N.C. L. REV. 931, 973-74 (1999).

4. See Jill I. Gross, Justice Scalia's Hat Trick and the Supreme Court's Flawed Understanding of Twenty-First Century Arbitration, 81 BrooK. L. REv. 111, 116-17 (2015).

5. See Lamps Plus, Inc. v. Varela, 139 S. Ct. 1407, 1415 (2019). "[T]he first principle that underscores all of our arbitration decisions" is that "[a]rbitration is strictly a matter of consent." Id.; see also Stolt-Nielsen S. A. v. AnimalFeeds Int'1 Corp., 559 U.S. 662, 682 (2010) (The "arbitrator derives his or her powers from the parties" agreement to forgo the legal process and submit their disputes to private dispute resolution."); Mitsubishi Motors Corp. v. Soler Chrysler-Plymouth, Inc., 473 U.S. 614, 628 (1985) ("By agreeing to arbitrate... [a party] trades the procedures and opportunity for review of the courtroom for the simplicity, informality, and expedition of arbitration.").

6. 9 U.S.C. $\S \S 1-16(2018)$.

7. Epic Sys. Corp. v. Lewis, 138 S. Ct. 1612, 1621 (2018) (reiterating that the FAA "requires courts 'rigorously' to 'enforce arbitration agreements according to their terms"" (quoting Am. Express Co. v. Italian Colors Rest., 570 U.S. 228, 233 (2013))).

8. Gross, supra note 4, at 132.

9. Imre Stephen Szalai, Exploring the Federal Arbitration Act Through the Lens of History, 2016 J. DISP. RESOL. 115, 119 (writing that the "FAA was part of a broader [procedural reform] movement ... to simplify court procedures, relieve overcrowded judicial dockets, and provide for improved, efficient methods of resolving disputes"). 
process would enhance participants' access to justice by simplifying what had become overly complex and unaffordable. 10

However, the increasing use of arbitration by commercial entities, particularly those with more bargaining power, has raised doubts about whether arbitration does in fact enhance access to justice relative to litigation. 11 Critics question whether there is true "consent" by the parties to arbitrate since so many arbitration proceedings stem from adhesive predispute arbitration clauses in consumer or employment contracts. 12 "Critical arbitration theory" posits that a system of mandatory arbitration, which has resulted from the Supreme Court's improper preference for binding arbitration over litigation, 13 delegates to private parties the power to alter or even strip substantive rights 14 _including the right to pursue claims through class or collective actions. 15 Critics claim this system suppresses

10. Margaret M. Harding, The Limits of the Due Process Protocols, 19 OHIO ST. J. ON DisP. RESOL. 369, 386 (2004) (citing COMM'N ON THE FutURE OF WORKER-MGMT. RELATIONS, FACT-FINDING REPORT 113 (1994), https://digitalcommons.ilr.cornell.edu/cgi/ viewcontent.cgi?article $=1279 \&$ context $=$ key_workplace [https:/perma.cc/GWD5-3G2A]) (citing a presidential commission report as identifying "private dispute resolution processes, including mediation and arbitration, as possible means to provide employees the access to justice they were being denied because of the high costs and delay of traditional litigation"); Stone, supra note 3, at 957-58 (summarizing arguments for why arbitration enhances disputants' substantive justice and stating that they will "get decisions based on common sense rather than on arcane legalisms").

11. See Alexander J. S. Colvin, Mandatory Arbitration and Inequality of Justice in Employment, 35 BERKELEY J. EMP. \& LAB. L. 71, 90 (2014) ("[R]ather than enhancing equality, mandatory arbitration exacerbates inequality in access to justice in the workplace."); Jean R. Sternlight, Disarming Employees: How American Employers Are Using Mandatory Arbitration to Deprive Workers of Legal Protection, 80 BROOK. L. REV. 1309, 1310 (2015) (critiquing employers' use of mandatory arbitration to decrease employees' access to justice); Thomas J. Stipanowich, The Arbitration Faimess Index: Using a Public Rating System to Skirt the Legal Logiam and Promote Fairer and More Effective Arbitration of Employment and Consumer Disputes, 60 U. KAN. L. REV. 985, 988-91 (2012) (identifying fairness concerns surrounding the growth of mandatory arbitration clauses).

12. Jacqueline Nolan-Haley, Does ADR's "Access to Justice" Come at the Expense of Meaningful Consent?, 33 OHIO ST. J. ON DISP. RESOL. 373, 386, 388-89, 396 (2018) ("The erosion of consent in ADR processes implicates the quality of justice to which the access to justice reform movement has aspired.").

13. See, e.g., Judith Resnik, The Privatization of Process: Requiem for and Celebration of the Federal Rules of Civil Procedure at 75, 162 U. PA. L. REV. 1793, 1809-14 (2014) (contending that Supreme Court decisions on arbitration "regularly rely on the Court's view that arbitration is to be preferred to adjudication"); Jean R. Sternlight, Panacea or Corporate Tool?: Debunking the Supreme Court's Preference for Binding Arbitration, 74 WASH. U. L.Q. 637, 673 (1996); see also Jill I. Gross, Rethinking the Debunking: On Arbitration Myths, Preferences and Legal Theory, in Discussions IN Dispute Resolution: The Formative ARTICLES (Hinshaw, Schneider \& Cole eds., forthcoming 2020).

14. See, e.g., David Horton, Arbitration as Delegation, 86 N.Y.U. L. REV. 437, 493 (2011); David S. Schwartz, Enforcing Small Print to Protect Big Business: Employee and Consumer Rights Claims in an Age of Compelled Arbitration, 1997 WIS. L. REV. 33, 110-21; Jean R. Sternlight, Rethinking the Constitutionality of the Supreme Court's Preference for Binding Arbitration: A Fresh Assessment of Jury Trial, Separation of Powers, and Due Process Concerns, 72 TuL. L. REv. 1,13 n.38 (1997).

15. See, e.g., Jean R. Sternlight, Mandatory Binding Arbitration Clauses Prevent Consumers from Presenting Procedurally Difficult Claims, 42 SW. L. REV. 87, 87-88 (2012). See generally Nancy A. Welsh \& Stephen J. Ware, Ross et al. v. American Express et al.: The 
valid claims of parties with little to no bargaining power16 and is even unconstitutional. 17

Furthermore, because arbitration awards typically are neither public nor precedential, critics have expressed alarm over the privatization and lack of public development (or "freezing") of the law for decades. 18 Indeed, in industries where virtually all disputes are arbitrated, the lack of any precedent reduces the value of the bargaining endowments that parties seeking to settle would have if they were settling a dispute headed to court as opposed to arbitration, as the shadow of the applicable law is murky or nonexistent. 19

Story Behind the Spread of Class Action-Barring Arbitration Clauses in Credit Card Agreements, DISP. RESOL. MAG., Fall 2014, at 18 (detailing a case in which a district court found concerted actions, including twenty-eight group meetings of issuer banks across the credit card industry, to include predispute arbitration clauses in customer agreements to suppress consumers' ability to bring class action suits against the industry).

16. See, e.g., Cynthia Estlund, The Black Hole of Mandatory Arbitration, 96 N.C. L. REV. 679,684 (2018) (citing "mounting evidence that it effectively enables employers to nullify employee rights and to insulate themselves from the liabilities that back up crucial public policies"); David S. Schwartz, Claim-Suppressing Arbitration: The New Rules, 87 IND. L.J. 239, 240 (2012); Jean R. Stemlight, Tsunami: AT\&T Mobility LLC v. Concepcion Impedes Access to Justice, 90 OR. L. REV. 703, 704 (2012).

17. Deborah R. Hensler \& Damira Khatam, Re-inventing Arbitration: How Expanding the Scope of Arbitration is Re-shaping Its Form and Blurring the Line Between Private and Public Adjudication, 18 NEV. L.J. 381, 381 (2018) (arguing that "re-inventing arbitration to adhere to public justice norms risks undermining its value for private actors with private disputes, while at the same time undermining courts as institutions for public contest over public policy issues"); Judith Resnik, Diffusing Disputes: The Public in the Private of Arbitration, the Private in Courts, and the Erasure of Rights, 124 YALE L.J. 2804, 2811 (2015) (arguing that the "cumulative impact of recent Supreme Court decisions on arbitration also produces an unconstitutional system, providing insufficient oversight of the processes it has mandated as a substitute for adjudication").

18. See, e.g., Myriam Gilles, The Day Doctrine Died: Private Arbitration and the End of Law, 2016 U. ILL. L. REV. 371, 376-77 (arguing that, because arbitration awards lack "[t]he stuff of the common law-stare decisis, publicity, and preclusion principles, . . common law doctrinal development will cease" for many types of cases); Maria Glover, Disappearing Claims and the Erosion of Substantive Law, 124 YALE L.J. 3052,3057 (2015) ("Through the procedural device of private arbitration, private parties have the quasi-lawmaking power to write substantive law largely off the books by precluding or severely impeding the assertion of various civil claims." ); Kathryn A. Sabbeth \& David C. Vladeck, Contracting (Out) Rights, 36 FORDHAM URB. L.J. 803, 807 (2009) (warning that, "[t]o the extent that we are considering wholesale acceptance of arbitration as a mandatory substitute for litigation, we must come to terms with the fact that we are sacrificing the public interpretation of public laws"); Jean R. Sternlight, Mandatory Arbitration Stymies Progress Towards Justice in Employment Law: Where to, \#MeToo?, 54 HARV. C.R.-C.L. L. REV. 155, 161 (2019) (arguing that the "imposition of mandatory arbitration stymies the progressive evolution of law"); Stephen Ware, Default Rules from Mandatory Rules: Privatizing Law Through Arbitration, 83 MinN. L. REV. 703, 704 (1999) (considering "the extent to which the creation of law has been privatized through arbitration" and suggesting "that, under Supreme Court cases and other current legal doctrine, vast areas of law are privatizable and that this degree of privatization is possible only through arbitration"); see also, e.g., Barbara Black \& Jill I. Gross, Making It Up as They Go Along: The Role of Law in Securities Arbitration, 23 CARDOZO L. REv. 991, 101326 (2002) (expressing concern over the freezing of law governing broker-dealers' obligations to customers).

19. See Jill I. Gross, Bargaining in the (Murky) Shadow of Arbitration, 24 HARV. NEGot. L. REV. 185, 190 (2019). As that article details, in areas of law where virtually all disputes are resolved in arbitration, little to no precedent develops because awards are private and rarely 
In addition to critiquing the "forced" nature of some arbitration proceedings, scholars claim that the process that results from an adhesive agreement to arbitrate is unfair, thus belying the access to justice narrative. ${ }^{20}$ Setting aside the consent critique, regardless of how a dispute enters arbitration, the disputant will want an arbitration process to be procedurally and substantively fair and ultimately to deliver justice. 21 However, critics contend that today's arbitration process has become too litigation-like, eliminating its advantages as a speedy, economical ADR process.22 Empirical studies have yielded the additional critique that the repeat-playerprocess advantages garnered by parties with superior bargaining power harm those with weaker bargaining power. 23 Finally, due to the strictly limited grounds for appeal and no requirement that arbitration awards include

include an explanation or reasoning. $I d$. at 198-203. The law in those areas is thus very uncertain, even murky, and parties attempting to settle a dispute that otherwise would go to arbitration are bargaining in this murky shadow. Id. Ultimately, this uncertainty leads parties to settle disputes for amounts that do not fully reflect the value of bargaining endowments that the shadow of the law would otherwise grant. $I d$.

20. See Nolan-Haley, supra note 12, at 377 ("[A]rbitration has actually limited access to justice within the context of consumer and employment arbitration, rather than enabled it.").

21. By acknowledging the concerns over the lack of meaningful consent to an adhesive agreement to arbitrate - but then setting them aside - this Article aims to focus readers on the process of arbitration itself, especially (1) because it seems unlikely that the Supreme Court will overturn decades of precedent that enforces adhesive arbitration agreements, see Epic Sys. Corp. v. Lewis, 138 S. Ct. 1612, 1619 (2018), and (2) since arbitration is here to stay, it is important that parties have the ability to assess whether arbitration enhances or decreases access to justice.

22. See Arthur R. Miller, Widening the Lens: Refocusing the Litigation Cost-and-Delay Narrative, 40 CARDOZO L. REV. 57, 87 (2018) ("Today's pressure for alternative dispute resolution is symptomatic of an attempt to respond to the overblown cost-and-delay narrative by hailing those procedures as a solution to litigation's perceived ills. But they profoundly constrict citizen access to the public courts in the name of efficiency and economy."); Thomas J. Stipanowich, Arbitration: The "New Litigation," 2010 U. LLL. L. REV. 1, 12-19 (describing changes in the nature of arbitration that made the process more like litigation).

23. Lisa B. Bingham, Employment Arbitration: The Repeat Player Effect, 1 EMP. RTs. \& EMP. POL'Y J. 189, 190-91 (1997); Jean R. Sternlight, Creeping Mandatory Arbitration: Is It Just?, 57 STAN. L. REV. 1631, 1650-51 (2005) ("Whereas a given company will tend to arbitrate many consumer disputes, a given consumer or employee will typically arbitrate, at most, one. Thus, the companies have far greater experience with and exposure to the arbitration process than do the consumers or employees. There is some limited empirical evidence that the repeat player does somewhat better in arbitration than the nonrepeat player."). But see Peter B. Rutledge, Whither Arbitration?, 6 GEO. J.L. \& PuB. PoL'Y 549, 567 (2008) (reviewing arguments and empirical studies regarding the repeat-player effect and concluding that "there is some support for the repeat-player phenomenon in the empirical literature, but the picture there is mixed at best"). 
reasons, 24 arbitration skeptics challenge the lack of accountability of the arbitration panels. ${ }^{25}$

Notably, these process critiques do not differentiate among types of arbitration. Instead, they assume that arbitration is a monolithic process. This assumption is false, however, as twenty-first-century arbitration can differ greatly depending on the industry in which the dispute arises 26 and the forum that administers the process pursuant to its own unique procedural rules. $^{27}$ Among these different forums, aspects of the process can vary regarding how to demand arbitration, requirements for initial pleadings, how many and how arbitrators are chosen, prehearing procedures allowed-such as discovery and dispositive motions - whether rules can be altered by the parties, forum fees, arbitrator fees, the length of the hearing, whether an award is published, and the requirements for an award.

In light of these vast differences in arbitration subtypes, it is neither possible nor accurate to conclude one way or the other whether "arbitration" enhances or decreases disputants' access to justice as compared to litigation. ${ }^{28}$ Rather, it depends on the arbitration "subtype." This Article proposes a framework to assess a limited question: whether a particular form of arbitration enhances disputants' access to justice relative to litigation. ${ }^{29}$ Part I attempts to define what "access to justice" means in the context of arbitration. Part II identifies process features that contribute to a finding that a subtype of arbitration increases parties' access to justice relative to litigation. Part III identifies a few specific types of arbitration that, when

24. See Oxford Health Plans LLC v. Sutter, 569 U.S. 564, 568 (2013) ("Under the FAA courts may vacate an arbitrator's decision 'only in very unusual circumstances.' That limited judicial review, we have explained, 'maintain[s] arbitration's essential virtue of resolving disputes straightaway." (first quoting First Options of Chi., Inc. v. Kaplan, 514 U.S. 938, 942 (1995); then quoting Hall St. Assocs., L. L. C. v. Mattel, Inc., 552 U.S. 576, 588 (2008))); Wallace v. Buttar, 378 F.3d 182, 190 (2d Cir. 2004) ("[A]rbitrators are not required to provide an explanation for their decision." (quoting Willemijn Houdstermaatschappij, BV v. Standard Microsystems Corp., 103 F.3d 9, 12 (2d Cir. 1997))).

25. See Richard C. Reuben, Democracy and Dispute Resolution: Systems Design and the New Workplace, 10 HARV. Negot. L. REV. 11, 42 (2005) (stating that "arbitration provides little accountability, as arbitration awards are generally not subject to the substantive review that is available for decisions in public adjudication").

26. For example, the baseball, domestic or international commercial, construction, international sports, investment treaty, labor, and securities industries.

27. For example, the American Arbitration Association (AAA), International Institute for Conflict Prevention and Resolution (CPR), the Financial Industry Regulatory Authority (FINRA), the Hong Kong International Arbitration Centre (HKIAC), the International Court of Arbitration of the International Chamber of Commerce (ICC), JAMS (originally called the Judicial Arbitration and Mediation Service), the London Court of International Arbitration (LCIA), National Arbitration and Mediation (NAM), and the Singapore International Arbitration Centre (SIAC)—-to name just a few.

28. The relevant comparator is litigation because the premise of the ADR movement is that ADR processes can enhance disputants' access to justice relative to what they have now, which is access to the courts.

29. This is a "limited use" framework, as the framework does not purport to assess the overall fairness or justice of an arbitration process. Rather, it attempts to answer the question posed by this Symposium-ADR and Access to Justice: Fact or Fiction? - and only in the context of arbitration. 
assessed against these features, more effectively deliver access to justice and thus can be considered "arbitration archetypes."

\section{WHAT IS "ACCESS tO JUSTICE"?}

Before evaluating whether a dispute resolution process enhances access to justice, we must define what "access to justice" means in this context. A recent historical perspective on the "access to justice" movement characterized it as "helping people gain access to fair representation in the courts, lowering legal costs, and reducing delays and the complexity of the justice systems." 30 Professor Jacqueline Nolan-Haley recently stated that "[t]he core values of the access to justice movement were understood as accessibility, and fairness."31 Fordham Law School's National Center for Access to Justice defines "access to justice" as follows:

Justice depends on having a fair chance to be heard, regardless of who you are, where you live, or how much money you have. At minimum, a person should be able to learn about her rights and then give effective voice to them in a neutral and nondiscriminatory, formal or informal, process that determines the facts, applies the rule of law, and enforces the result. 32

In the context of dispute resolution processes, a noted ADR scholar recently defined access to justice as follows:

1. Access to Process - can parties easily access a dispute resolution forum in a cost conscious manner

2. Access to Lawyers Plus - can parties access helping professionalslawyers, but also financial counselors or special education advocates, etcin order to support informed decision-making

3. Access to Better/Fairer Outcomes-are ADR processes providing parties with the opportunity to use their voice and influence the outcome of their disputes. ${ }^{33}$

30. Hadas Cohen \& Michal Alberstein, Multilevel Access to Justice in a World of Vanishing Trials: A Conflict Resolution Perspective, 47 FordHAM URB. L.J. 1, 5 (2019).

31. Nolan-Haley, supra note 12 , at 380 . Before the Trump administration shuttered the U.S. Department of Justice's Office for Access to Justice, the office defined "access to justice" as guided by three principles: (1) "Promoting Accessibility —eliminating barriers that prevent people from understanding and exercising their rights"; (2) "Ensuring Fairness-delivering fair and just outcomes for all parties, including those facing financial and other disadvantages"; and (3) "Increasing Efficiency-delivering fair and just outcomes effectively, without waste or duplication." Office for Access to Justice, U.S. DEP'T JUST. ARCHIVES, https://www.justice.gov/archives/atj [https://perma.cc/42J7-K3JS] (last visited Apr. 12, 2020).

32. Justice Index 2016, FordhaM L. SCH. NAT'L CTR. FOR ACCESS TO JUST., https://justiceindex.org/ [https://perma.cc/R9AM-3QE3] (last visited Apr. 12, 2020). Notably, fairness includes both substantive components - equitable outcomes based on legal rightsand procedural components-opportunity to be heard. See Nancy A. Welsh, Remembering the Role of Justice in Resolution: Insights from Procedural and Social Justice Theories, $54 \mathrm{~J}$. LEGAL EDUC. 49, 52 (2004).

33. Andrea Schneider, Access to Justice \& ADR—What Does This Even Mean?, INDISPUTABLY (June 22, 2019), http://indisputably.org/2019/06/access-to-justice-adr-whatdoes-this-even-mean/ [https://perma.cc/AP4Z-EUUM]. 
The common elements from these definitions (and many others) include efficient, cost-conscious and accessible processes, and fair outcomes. ${ }^{34}$ What do these elements mean in the context of arbitration? In other words, what features of the arbitration process make it efficient, inexpensive, accessible, and fair such that they increase access to justice relative to litigation? Once those features are identified, they can be measured against courtroom-based adjudication.

\section{Arbitration Features That Enhance AcCess to Justice}

This Part identifies those features of an arbitration process that contribute to a finding that the process increases a party's access to justice relative to litigation. This inquiry does not identify all features of the process that make it fair; access to justice is only one component of fairness.

As a threshold matter, all types of arbitration must include certain common process characteristics - otherwise the process would not be defined as "arbitration" under the FAA. ${ }^{35}$ These characteristics include: a neutral decision maker, 36 notice of a hearing, a full and fair opportunity to be heard, ${ }^{37}$

34. Cohen \& Alberstein, supra note 30 , at 7 ("Current understanding of access to justice has come to conceptualize this principle as including both accessibility (access to courts that can offer litigants just results based on the law) and fairness in the legal process itself.").

35. See, e.g., Rush Prudential HMO, Inc. v. Moran, 536 U.S. 355, 382 (2002) ("In the classic sense, arbitration occurs when "parties in dispute choose a judge to render a final and binding decision on the merits of the controversy and on the basis of proofs presented by the parties.' ... Arbitrators typically hold hearings at which parties may submit evidence and conduct cross-examinations." (citations omitted) (quoting 1 I. MACNEL ET AL., FEDERAL ARBITRATION LAW § 2.1.1 (1995))); see also Elkouri \& Elkouri, How ARBITRATION WORKS 1-3 (Kenneth May ed., 8th ed. 2016) (noting that arbitration is "voluntarily chosen by parties who want a dispute determined by an impartial judge of their own mutual selection, whose decision, based on the merits of the case, they agree in advance to accept as final and binding").

36. Some forums permit the appointment of a "party arbitrator," who is presumed to be partisan. In this arbitration model, each party selects a party arbitrator, and those two nonneutral panelists select a neutral chairperson. Thus, at least one arbitrator is neutral. See, e.g., Commercial arbitration Rules \& Mediation Procedures r. 13 (Am. ARbitration Ass'N 2016).

37. See Burchell v. Marsh, 58 U.S. (17 How.) 344, 349 (1854) (confirming an award in a commercial dispute between a retailer and two wholesalers and stating that, "after a full and fair hearing of the parties, a court of equity will not set it aside for error, either in law or fact"); Nationwide Mut. Ins. Co. v. Home Ins. Co., 278 F.3d 621, 625 (6th Cir. 2002) ("Fundamental fairness requires only notice, an opportunity to present relevant and material evidence and arguments to the arbitrators, and an absence of bias on the part of the arbitrators." (quoting La. D. Brown 1992 Irrevocable Tr. v. Peabody Coal Co., No. 99-3322, 2000 WL 178554, at *5-6 (6th Cir. Feb. 8, 2000))); see also Tracey B. Frisch, Death by Discovery, Delay, and Disempowerment: Legal Authority for Arbitrators to Provide a Cost-Effective and Expeditious Process, 17 CARDOZO J. CONFLICT Resol. 155, 156 (2015) ("Courts have confirmed awards so long as the arbitrators' refusal to hear evidence or deny discovery requests did not deprive the party of a fundamentally fair hearing."); Jill I. Gross, McMahon Turns Twenty: The Regulation of Fairness in Securities Arbitration, 76 U. CIN. L. REV. 493, 506 (2008) ("[T]oday's FAA jurisprudence makes it incontrovertible that an arbitration hearing arising under the FAA must include the classic hallmarks of fairness: notice, a right to be heard, and a neutral decision-maker."). 
and a binding award 38 Under the FAA, any award resulting from an arbitration process that does not provide the parties with a full and fair opportunity to be heard risks vacatur. ${ }^{39}$ In addition, under the FAA, prevailing parties have the ability to convert the award into a court-enforced judgment, 40 and losing parties can seek to modify or vacate an award for process deficiencies. 41

Beyond these common criteria, additional characteristics contribute to a process's efficiency and substantive fairness. However, not all arbitration subtypes share the additional process characteristics that are critical to a conclusion that the process enhances parties' access to justice when compared to litigating the same claims and defenses in court. And not all process characteristics of arbitration subtypes are equally important to this assessment. Thus, it is critical to identify which of these additional process features are most essential to enhancing access to justice.

In order for a subtype of arbitration to enhance parties' access to justice, in addition to the common features identified above, it is critical that the process: (1) cost less and take less time than litigating the same claim in court; (2) result in a published, explained award; (3) does not strip the rights of the parties to assert any claim, remedy, or procedure that would be available in court; and (4) permit the parties to be represented. The following sections explain why these four features are the most important.

\section{A. Cost and Speed}

To conclude that a process enhances a party's access to justice when compared with litigation in court, the costs of the arbitration process first and foremost should be at least equal to or less than the costs of resolving the same claims or defenses in court through the litigation process. ${ }^{42}$ In the

38. While nonbinding arbitration exists (sometimes called "advisory arbitration"), arbitration within the meaning of the FAA and arbitration in the classical sense are presumed to be binding unless otherwise indicated. See Amy J. Schmitz, Ending a Mud Bowl: Defining Arbitration's Finality Through Functional Analysis, 37 GA. L. REV. 123, 145-47 (2002) (arguing that the FAA governs only dispute resolution processes that yield final, binding decisions that are subject to only limited review by the courts); Thomas J. Stipanowich, Contract and Conflict Management, 2001 WIS. L. REV. 831, 840 (noting that FAA arbitration "contemplates a procedure before one or more private third party decision makers ('arbitrators'), and an adjudicative process of some kind culminating in a final decision ("award')" that is binding on the parties).

39. See 9 U.S.C. $\& 10(a)(3)$ (2018) (authorizing courts to vacate an award on proof that "the arbitrators were guilty of misconduct in refusing to ... hear evidence pertinent and material to the controversy"). Courts have held, however, that a document-only arbitration meets the requirement of fundamental fairness. See Jill I. Gross, AT\&T Mobility and the Future of Small Claims Arbitration, 42 Sw. L. REv. 47, 83 (2012) (arguing that, to ensure procedural justice, "dispute systems designers should give serious consideration to offering an oral hearing alternative" to paper hearings in small claims arbitration).

40. See 9 U.S.C. $\$ 9$ (providing means to confirm an arbitration award in federal district court).

41. See id. $\S \S 10-11$ (providing grounds to vacate and modify arbitration awards in federal district court).

42. Most commentators agree that court systems are plagued by high costs and inordinate delays. See, e.g., Cohen \& Alberstein, supra note 30, at 5 (describing the access to justice 
United States, both litigation and arbitration require parties to pay two different types of costs: forum fees and attorney's fees. Unlike in litigation, however, in arbitration, the parties must also compensate the arbitrators for their time. 43

In litigation, the plaintiff must pay a filing fee of just a few hundred dollars, regardless of the size of the claim. ${ }^{44}$ In addition, the losing party might have to pay nominal "court costs," which could include the plaintiff"s filing fee. ${ }^{45}$ If the litigant cannot afford the filing fee and can demonstrate indigency, applicable statutes in federal courts authorize the court to waive the fee. 46 The forum fees do not vary based on the dollar value of claim, and no additional payments are required to compensate the judge or jury. 47 The largest component of costs in litigation is attorney's fees, especially for attorneys' time spent on extensive motion practice and discovery. ${ }^{48}$

In arbitration, forum fees often are higher than forum fees in litigation and could include filing fees, session hearing fees, and arbitrator fees. ${ }^{49}$ Typically the claimant pays a filing fee to initiate the claim, which rises as the dollar value of the claim rises, and additional forum fees for each hearing session..$^{50}$ These forum fees often total in the thousands of dollars, rather than hundreds. 51 In addition, unlike in court, parties jointly pay hourly or

movement and noting that it "highlighted barriers in legal procedures including costly litigation"); John S. Kieman, Reducing the Cost and Increasing the Efficiency of Resolving Commercial Disputes, 40 CARDOZO L. REV. 187, 189 (2018) (stating that "the vast majority of disputes exist in a range of controversy that makes litigating to a decision unaffordable as a practical matter"). But see Miller, supra note 22, at 65 (critiquing the "persistence of the cost-and-delay narrative" without supporting data).

43. See, e.g., Commercial Arbitration Rules \& Mediation Procedures r. 55 (Am. ARBITRATION ASS'N 2016).

44. The filing fee to initiate a complaint in federal district court is $\$ 350.28$ U.S.C. $\S$ 1914(a) (2018). Filing fees in state courts are either comparable or lower. See, e.g., Filing Fees, N.Y. CTS. (Jan. 17, 2020), https://www.nycourts.gov/forms/filingfees.shtml [https:// perma.cc/695M-GKTJ. For example, to file a civil action in a New York State court, a plaintiff must pay $\$ 210$ to buy an "index number" and then an additional fee of less than $\$ 100$ for a court intervention or decision on a motion. See id. New York courts may also waive a filing fee on demonstration of financial hardship. N.Y. C.P.L.R. 1101(d) (MCKINNEY 2020).

45. See 10 James WM. Moore, MoOre’s Federal Practice $\$ 54.104$ (3d ed. 2020)

46. E.g., 28 U.S.C. $\$ 1914$ (a) (authorizing waiver of all but $\$ 5$ of the fee).

47. See id. \& 1915 .

48. Victor Marrero, The Cost of Rules, the Rule of Costs, 40 CARDOzo L. REV. 293, 340 (2018).

49. See, e.g., Commercial arbitration Rules \& Mediation Procedures rr. 53-56 (AM. ARBITRATION ASS'N 2016) (identifying types of fees parties must pay to continue with an arbitration); 12900. Fees Due When a Claim Is Filed, FINRA: RULES \& GUIDANCE (Dec. 15, 2014), https://www.finra.org/rules-guidance/rulebooks/finra-rules/12900 [https:// perma.cc/PD6R-75QL] (setting forth filing fees); 12902. Hearing Session Fees, and Other Costs and Expenses, FINRA: Rules \& GUIDANCE (Dec. 15, 2014), https://www.finra.org/rules-guidance/rulebooks/finra-rules/12902 [HTTPS://PERMA.CC/8QXFD9HT] (setting forth hearing session fees).

50. See supra note 49.

51. Clyde W. Summers, Mandatory Arbitration: Privatizing Public Rights, Compelling the Unwilling to Arbitrate, 6 U. PA. J. LAB. \& EMP. L. 685, 697-98 (2004). 
daily rates to compensate the neutrals. ${ }^{52}$ In some forums (for example, the Financial Industry Regulatory Authority (FINRA)), the cost of the arbitrator is built into each party's session fee; 53 at others (for example, the American Arbitration Association (AAA)), parties pay arbitrator fees on top of the amounts listed in fee schedules. 54 Hourly rates of arbitrators could be more than $\$ 500$ or even $\$ 1000$ per hour, depending on the industry and the experience of the arbitrator. ${ }^{55}$ And the hours can add up quickly as many hearings take days or even weeks, not just hours.

The other important difference in costs between arbitration and litigation is attorney's fees: arbitration typically has far less motion practice and more restricted discovery than litigation. 56 Though the empirical evidence is not conclusive, 57 some scholars contend that, because motion practice and discovery is far more limited in arbitration than in litigation and thus attorney's fees are lower, arbitration is still less expensive overall to pursue an award than litigation for a similar type of case.

In most cases, if an arbitration party cannot pay filing or other forum fees, then the party cannot proceed with the arbitration. ${ }^{58}$ However, the Supreme

52. See Costs of Arbitration, AM. ARB. Ass'N, https://www.adr.org/sites/default/files/ document_repository/AAA228_Costs_of_Arbitration.pdf [https://perma.cc/594L-XXKV] (last visite-d Apr. 12, 2020).

53. See, e.g., 12902. Hearing Session Fees, and Other Costs and Expenses, supra note 49.

54. See, e.g., Costs of Arbitration, supra note 52.

55. See generally Deborah Rothman, Trends in Arbitrator Compensation, DISP. RESOL. MAG., Spring 2017, at 8.

56. Schwartz, supra note 14 , at 60 (stating that arbitration generally eliminates pretrial motion and discovery practice and that the informality of arbitration means less time preparing for hearing and presenting evidence).

57. See Christopher R. Drahozal \& Samantha Zyontz, An Empirical Study of AAA Consumer Arbitrations, 25 OHIO ST. J. ON DISP. RESOL. 843, 850 (2010); Gross, supra note 4, at 139; Stephen J. Ware, Is Adjudication a Public Good?: "Overcrowded Courts" and the Private Sector Alternative of Arbitration, 14 CARDozo J. ConfliCt RESOL. 899, 907 n.31 (2013) (stating that "[t]he evidence indicates that arbitration tends to have lower process costs than litigation" and that "[a]rbitration's process costs may be so much lower than litigation's as to more than make up for arbitration's higher adjudicator costs"). But see Christopher R. Drahozal, Arbitration Costs and Forum Accessibility: Empirical Evidence, 41 U. MICH. J.L. REFORM 813, 815-16 (2008) (concluding that arbitration may be as costly or more costly than litigation for certain types of disputes and less costly for other types); Lisa A. Nagele-Piazza, Unaffordable Justice: The High Cost of Mandatory Employment Arbitration for the Average Worker, 23 U. MIAMI BUS. L. REV. 39, 42 (2014) (arguing that costs of employment arbitration for workers may prevent workers from vindicating their statutory rights).

58. See, e.g., Commercial arbitration Rules \& Mediation Procedures r. 4(b)(ii) (AM. ARBITRATION ASS'N 2016) (providing that "[t]he filing fee must be paid before a matter is considered properly filed"); $i d$. r. 57(b) (providing remedies for nompayment of arbitrator fees, including "limiting a party's ability to assert or pursue their claim"). However, some courts have held that parties that cannot afford to proceed in arbitration can instead pursue their claims in court despite the existence of an otherwise enforceable arbitration agreement. See, e.g., Tillman v. Tillman, 825 F.3d 1069, 1073-74 (9th Cir. 2016) (permitting a lawsuit to go forward in court despite the existence of a valid arbitration agreement because the arbitrator had dismissed the arbitration after one party could not afford to pay her share of the arbitrator fees on the grounds that "arbitration has been had" within the meaning of FAA $\S 3$ ); Pre-paid Legal Servs., Inc. v. Cahill, 786 F.3d 1287, 1294 (10th Cir. 2015) (lifting a stay of action 
Court has held that an arbitration agreement is enforceable for federal statutory claims even if a party is unable to afford the costs of the arbitration process. ${ }^{59}$ As a result, an indigent party would only be able to afford the arbitration process if a forum provides a fee waiver for demonstrated financial hardship or if another entity absorbs the cost.

Related to cost is speed, as time often translates to money for disputants. To enhance parties' access to justice, arbitration should also lead to a resolution more quickly than litigation in court. The longer a process takes from initial filing to enforcement of an award, the less justice is delivered to the parties.

Of course, the duration of a civil case in court varies greatly depending on the means of disposition (dismissed after motion, settled, or judgment after trial), the court (state or federal), and the type of case (simple breach of contract or complex corporate litigation). In federal court, recent statistics report that, nationally, the median time of a civil case from filing to trial is 27.8 months, ${ }^{60}$ though even that median varies greatly depending on the district. ${ }^{61}$ In state courts, a recent empirical study found that the mean length of time for civil cases from filing to disposition was 306 days, though some outliers of twenty years or more were reported. 62 In contrast, generally speaking, arbitration forums report faster resolution times for their cases. ${ }^{63}$

In sum, if parties must pay higher filing and other forum fees to pursue the same claims as in court and must compensate attorneys for substantial hours, then the arbitration process decreases, as opposed to enhances, parties' access to justice. If parties can get to a resolution faster than in court, then the arbitration process enhances their access to justice.

pending arbitration because the employee-defendant failed to pay his share of arbitration fees and the arbitrators terminated arbitration).

59. Am. Express Co. v. Italian Colors Rest., 570 U.S. 228, 236-37 (2013) (holding that an arbitration agreement is enforceable even if it strips a part of the ability to sue, so long as it does not strip a party's right to sue). The Court did recognize, in dicta, that it could envision a situation where an arbitration agreement might not be enforceable because "filing and administrative fees attached to arbitration ... are so high as to make access to the forum impracticable." Id. at 236.

60. United States District Courts-National Judicial Caseload Profile, U.S. CTS., https://www.uscourts.gov/sites/default/files/data_tables/fcms_na_distprofile0930.2019.pdf [https://perma.cc/9J6Y-ATKB] (last visited Apr. 12, 2020) (covering the twelve-month period ending September 30, 2019).

61. See generally id.

62. Nat'L Ctr. for State Courts, Civil Justice Initiative: The Landscape of LitiGATION IN STATE COURTS 28 (2019), https://www.ncsc.org/ /media/Files/PDF/Research/ CivilJusticeReport-2015.ashx [https://perma.cc/ZC4X-4KVU] (reporting the results of an empirical study of 152 state courts in ten counties across the country of all cases disposed of from July 1,2012 to June 30,2013 ).

63. See, e.g., Measuring the Costs of Delays in Dispute Resolution, Am. ARB. Ass'N, https://go.adr.org/impactsofdelay.html [https://perma.cc/H5HS-2WYF] (last visited Apr. 12, 2020) (reporting an average time of 11.6 months to get to the adjudication phase for AAA filings). 


\section{B. Published, Explained Award}

To provide at least the same access to justice as courts, arbitration forums must publish their arbitrators' awards just as courts do. ${ }^{64}$ In court, outcomes of civil cases are published via a "judgment" filed with the court clerk. ${ }^{65}$ That judgment memorializes a verdict or a decision on a dispositive motion so that the public is aware of outcomes, even if it is not aware of the reasons for a jury's verdict or a disposition. 66

Publication ensures some accountability.67 Absent a public memorialization of the outcome, like a court judgment, disputants cannot be sure that the arbitration neutral decided the case pursuant to the powers granted to it by the parties in the arbitration agreement. ${ }^{68}$ Additionally, cognitive psychology research suggests that people exert greater efforts to improve the quality of their decision-making when they are more likely to be held accountable for their decisions. 69

To enhance access to justice in arbitration relative to litigation, arbitrators must also issue an explained award by including a rationale for the outcome. 70 An "explained award" is not the same thing as a fully reasoned court opinion. As the Second Circuit explained:

[A] reasoned award is something more than a line or two of unexplained conclusions, but something less than full findings of fact and conclusions of law on each issue raised before the panel. A reasoned award sets forth

64. Though no statute requires an award to be in writing, most arbitration forums require that awards be in writing and signed by a majority of panelists. See, e.g., COMMERCIAL ARBITRATION RUles \& Mediation PRocedures r. 46(a) (AM. ARBitration Ass'N 2016); 13904. Awards, FINRA: RULEs \& GUIDANCE (Feb. 21, 2018), https://www.finra.org/rulesguidance/rulebooks/finra-rules/13904 [https://perma.cc/VTN8-X3WT].

65. See FED. R. CIV. P. 58

66. See id.

67. Though an explained award does make arbitrators even more accountable, juries are not required to explain their verdicts. Thus, arbitration awards even without explanations provide parties with access to the same brand of justice as they could obtain in court.

68. See United Steelworkers of Am. v. Enter. Wheel \& Car Corp., 363 U.S. 593, 597 (1960) (" $[\mathrm{A}] \mathrm{n}$ arbitrator is confined to interpretation and application of the collective bargaining agreement; he does not sit to dispense his own brand of industrial justice. He may of course look for guidance from many sources, yet his award is legitimate only so long as it draws its essence from the collective bargaining agreement.").

69. See Sarah Rudolph Cole, Fairness in Securities Arbitration: A Constitutional Mandate?, 26 PACE L. REV. 73, 107-08 (2005); see also Mark Seidenfeld, Cognitive Loafing, Social Conformity, and Judicial Review of Agency Rulemaking, 87 CORNELL L. REV. 486, 513 (2002) (" [I]f accountability is to improve an ultimate decision, the decisionmaker must be aware that he will be held accountable prior to making a commitment.").

70. However, it is well accepted that an "arbitrator's rationale for an award need not be explained" unless the parties specify that requirement in their arbitration agreement. D.H. Blair \& Co. v. Gottdiener, 462 F.3d 95, 110 (2d Cir. 2006); see also Smarter Tools Inc. v. Chongqing SENCI Imp. \& Exp. Trade Co., No. 18-CV-2714 (AJN), 2019 WL 1349527, at *3 (S.D.N.Y. Mar. 26, 2019) (Parties can contract to "require arbitrators to issue more detailed awards."). 
the basic reasoning of the arbitral panel on the central issue or issues raised before it. It need not delve into every argument made by the parties. ${ }^{71}$

An explained award enhances parties' procedural justice. Parties that can understand the basic rationale for the outcome of their dispute are more likely to feel as if they have been heard. ${ }^{72}$ To ensure that arbitrators based their outcome on applicable rules of law and principles of equity, parties must be able to ascertain the basis of the arbitrators' decision, even if they do not understand the full reasoning. ${ }^{73}$ If disputants believe the process is random or arbitrary, they may lose faith in it. ${ }^{74}$

Arbitration opponents claim that, because they do not have to fully reason their awards like judges, arbitrators do not observe the rule of law. ${ }^{75}$ Indeed, under the FAA, parties cannot challenge an arbitration award merely for an error of law but only if arbitrators manifestly disregard the law. ${ }^{76}$ Thus, it is hard to discern whether the arbitrators followed the law when deliberating. However, the promise of arbitration is a decision not just based on the law but based on law combined with equity. It is hard to argue that applying equitable principles does not enhance fairness.

71. Leeward Constr. Co., Ltd. v. Am. Univ. of Ant.-Coll. of Med., 826 F.3d 634, 640 (2d Cir. 2016). Several other circuits have adopted substantially similar definitions of a reasoned award. See, e.g., Sabre GLBL, Inc v. Shan, 779 F. App'x 843, 855 (3d Cir. 2019); Rain CII Carbon, LLC v. ConocoPhillips Co., 674 F.3d 469, 473 (5th Cir. 2012); see also Cat Charter, LLC V. Schurtenberger, 646 F.3d 836, 844 (11th Cir. 2011) ("[A] 'reasoned' award is an award that is provided with or marked by the detailed listing or mention of expressions or statements offered as a justification of an act - the 'act' here being, of course, the decision of the Panel.").

72. See Jill I. Gross \& Barbara Black, When Perception Changes Reality: An Empirical Study of Investors 'Views of the Fairness of Securities Arbitration, 2008 J. DISP. RESOL. 349, 395 "This desire for explained outcomes is consistent with procedural justice theorists who value transparency in decision-making.")

73. I previously have explained why a full-blown reasoned award is problematic because it "risks that arbitrators will be more reluctant to infuse equity into their decision-making and awards will be more vulnerable to vacatur motions." Id.

74. See id. (theorizing that "[d] epriving participants of [transparent awards] may very well foster negative views of the process as a whole"); see also Barbara Black \& Jill I. Gross, The Explained Award of Damocles: Protection or Peril in Securities Arbitration, 34 SEC. REG. L.J. 17, 19-23 (2006) (identifying drawbacks of awards without explanation and benefits of requiring arbitrators to explain their awards); Richard C. Reuben, Democracy and Dispute Resolution: The Problem of Arbitration, LAW \& ConTEMP. PRoBs., Winter/Spring 2004, at $279,289,301$ (identifying transparency as a value in democratic processes and stating that "[ $\mathrm{t}$ ]ransparency is generally not an animating value of arbitration" because arbitrators are not required to include reasons in their awards).

75. See Gilles, supra note 18, at 411 ("[A]rbitrators themselves are not bound to follow precedent, but instead, "are given wide latitude in their interpretation of legal concepts." (quoting Edward Brunet \& Jennifer J. Johnson, Substantive Faimess in Securities Arbitration, 76 U. CIN. L. REV. 459, 477 (2008))); see also Edward Brunet \& Jennifer J. Johnson, Substantive Fairness in Securities Arbitration, 76 U. CIN. L. REV. 459, 460 (2008) (arguing that arbitrators should apply the rule of law because "[a] dispute resolution system without any guarantees of nule application gives the parties little or no notice of the ratio decidendi of the arbitration").

76. See Gilles, supra note 18, at 412 ("[T]he Supreme Court has repeatedly held that arbitration is final and binding, subject to review only where arbitrators evince a "manifest disregard' of the law." (quoting Hall St. Assocs., L. L. C. v. Mattel, Inc. 552 U.S. 576, 586 (2008))). 


\section{Absence of Right-or Remedy-Stripping Procedural Rules}

The rules of the arbitration forum also must permit the parties to pursue all the rights and remedies they would have for the same claim if it were pursued in court. 77 If a party can be denied the right to bring certain claims that they otherwise could bring in court or assert certain remedies that they could otherwise assert in court, then that process surely limits access to justice. Examples could include forum rules restricting the arbitrator's power to award punitive damages or attorney's fees when they would be available in court or to allow joinder of similar claims. Thus, whether the arbitration forum's procedural rules reduce or eliminate a party's ability to pursue its full rights and remedies - as would be available in court - is a significant factor when measuring access to justice.

\section{Right to Representation}

Finally, to ensure that parties do not lose access to justice in arbitration and have the ability to assert their rights effectively, the forum must permit parties to be represented by a lawyer or other chosen representative. 78 Recent empirical studies have shown that parties fare better in arbitration if they are represented by counsel. 79 The arbitration process is different from court but can be similarly intimidating for the unfamiliar. In addition, commentators have raised concern regarding the advantage of "repeat players"- those parties who regularly arbitrate disputes in connection with their business and thus are very familiar with the process and regularly compensate arbitrators for their time .80 Just as repeat players might gain an advantage from their

77. This process characteristic is distinguished from right- or remedy-stripping clauses in the agreement to arbitrate. For example, many scholars contend that the now common use of a class or collective action waiver alongside an agreement to arbitrate precludes parties from bringing class or collective claims. See supra note 15 and accompanying text. Nevertheless, the Supreme Court has held that these waivers are enforceable. See Epic Sys. Corp. v. Lewis, $138 \mathrm{~S}$. Ct. 1612, 1623 (2018) (enforcing a class action waiver in an employment arbitration agreement); AT\&T Mobility LLC V. Concepcion, 563 U.S. 333, 351 (2011) (enforcing a class action waiver in a consumer arbitration agreement).

78. I am not aware of any arbitration forum that bans parties from being represented if they so choose. Some forums, such as FINRA, have explored amending their rules to ban nonattorney representatives from representing parties as a means to prevent exploitation of investors, not as a means to decrease access to justice. See Benjamin P. Edwards, FINRA Seeking to Ban Non-attorney Representatives (a/k/a NARs), BUS. L. PROF BLOG (Dec. 27, 2018), https://awprofessors.typepad.com/business_law/2018/12/finra-seeking-to-ban-nonattorney-representatives-aka-nars.html [https://perma.cc/V2SA-538C].

79. Emily S. Taylor Poppe \& Jeffrey J. Rachlinski, Do Lawyers Matter?: The Effect of Legal Representation in Civil Disputes, 43 PEPP. L. REV. 881, 885 (2016). The authors gathered existing empirical research and "conclude[d] that the evidence strongly supports the conclusion that representation benefits clients. The vast majority of the studies provide evidence that represented parties obtain more favorable outcomes than unrepresented parties, although a handful of studies suggest the opposite." Id. But see David Horton \& Andrea Cann Chandrasekher, After the Revolution: An Empirical Study of Consumer Arbitration, 104 GEO. L.J. 57, 106 (2015) (reporting the results of an empirical study finding that some unrepresented parties reached better outcomes in arbitration than represented ones).

80. See supra note 23 and accompanying text. 
familiarity with arbitration, nonrepeat, unrepresented players are at a disadvantage due to their lack of familiarity. ${ }^{81}$

\section{ARBitration ARChETypes to Enhance ACCEsS to Justice}

Are there any arbitration processes that include all of the features that are critical to enhance access to justice? It certainly is easier to identify those arbitration subtypes that do not have the features. For example, international commercial (i.e., cross-border commercial transactions) disputes; investment treaty (i.e., international investments governed by treaties) disputes, 82 domestic commercial (i.e., B2B transactions) disputes, construction disputes, international sports disputes, ${ }^{83}$ and investor-state employment disputes are all eliminated because of their high unsubsidized costs. ${ }^{84} \mathrm{I}$ can also eliminate "final offer" or "baseball" arbitration, used by Major League Baseball to resolve salary disputes for arbitration-eligible baseball players, because the process eliminates virtually all allowable outcomes except two: either the claimant's requested compensation or the team's. 85 This reduces access to justice for the disputants by eliminating their ability to seek a full range of remedies from a panel.

Below, I identify two "arbitration archetypes"-specific subtypes of arbitration that contain all of the features identified in Part III: grievance (rights-based) arbitration pursuant to a collective bargaining agreement (CBA) and customer arbitration at FINRA.

\section{A. Grievance Arbitration}

Labor arbitration "describes an arrangement where a union and an employer agree in a CBA to resolve disputes over the meaning of the CBA

81. See Horton \& Chandrasekher, supra note 79 , at 57 (reporting on empirical study finding that "frequently arbitrating entities win more and pay less in damages than one-shot entities" but finding lack of repeat-player effect in certain consumer arbitration matchups); see also Bingham, supra note 23, at 191 (arguing that the repeat-player effect exists in employment arbitration).

82. For a good description of international commercial arbitration and its differences from investment treaty arbitration, see S. I. Strong, Navigating the Borders Between International Commercial Arbitration and U.S. Federal Courts: A Jurisprudential GPS, 2012 J. DISP. RESOL. 119, 125-26.

83. The Court of Arbitration for Sport (CAS) arbitrates disputes arising out of international sports competitions, including the Olympics. Though the International Council of Arbitration and Sport, an oversight body, has created a legal aid fund to pay the attorney's fees of athletes who lack the means to pay, athletes still have to pay substantial forum fees and arbitrators' hourly rates. See Matthew J. Mitten, The Court of Arbitration for Sport and Its Global Jurisprudence: International Legal Pluralism in a World Without National Boundaries, 30 OHIO ST. J. ON DISP. Resol. 1, 2l-22 (2014) (describing the international and Olympic sports arbitration system and exploring its fairness).

84. See generally Susan D. Franck, Rationalizing Costs in Investment Treaty Arbitration, 88 WASH. U. L. REV. 769 (2011).

85. See Jeff Monhait, Baseball Arbitration: An ADR Success, 4 HARV. J. SPORTS \& ENT. L. $105,112(2013)$. 
in a grievance process that culminates in binding arbitration." 86 Most grievance arbitrations are administered either by the AAA or the Federal Mediation and Conciliation Service (FMCS).87 Grievance arbitration includes all of the criteria for a process that enhances access to justice as compared to litigation: low cost, 88 speed, 89 published and explained awards, ${ }^{90}$ no right-stripping procedural rules, ${ }^{91}$ and the right to representation. ${ }^{92}$ Also, it provides for party control 93 and an oral hearing unless the parties waive it.94 Thus, labor arbitration is an arbitration archetype.

\section{B. FINRA Customer Arbitration}

Arbitration in the securities industry between investors and brokerage firms for disputes arising from account activity or between individual brokers and their employing firms also contains the criteria important to enhance access to justice. FINRA subsidizes most of the cost of the forum for investors and associated claimants (including the cost of arbitrators), ${ }^{95}$ publishes all awards on its website, 96 expressly prohibits any claim- or remedy-stripping provisions, ${ }^{97}$ and provides a right to representation. 98 Further, FINRA has an average turnaround time for a claim of just over one

86. See Ariana R. Levinson, What the Awards Tell Us About Labor Arbitration of Employment-Discrimination Claims, 46 U. MICH. J.L. REFORM 789, 794 (2013) (describing the process of labor arbitration). For a thorough description of the process of grievance arbitration, see generally JAY E. GRENIG \& ROCCO M. SCANZA, FUNDAMENTALS OF LABOR ARBITRATION (2011).

87. See generally GRENIG \& SCANZA, supra note 86.

88. The AAA Schedule of Fees for Labor Arbitration sets a $\$ 275$ flat filing fee. The union provides the worker with a representative and pays the worker's share of the costs of arbitration, so the process is affordable and accessible for workers. See Levinson, supra note 86, at 843; see also Nagele-Piazza, supra note 57 , at 43.

89. See Levinson, supra note 86 , at $815-17$.

90. LABOR ARBITRATION r. 37 (AM. ARBITRATION ASS'N 2015) (indicating that the default rule is that arbitrators must include opinions with their awards). Labor awards are published on legal research databases such as LexisNexis and Westlaw. Cf. 29 C.F.R. $§ 1404.14$ (2019) ("While FMCS encourages the publication of arbitration awards, arbitrators should not publicize awards if objected to by one of the parties.").

91. Cf. LABOR ARBITRATION r. 47 ("The arbitrator shall interpret and apply these rules insofar as they relate to the arbitrator's powers and duties.").

92. Id. r. 18 .

93. Id. $\mathrm{r}$. 1 ("The parties, by written agreement, may vary the procedures set forth in these rules.").

94. Id. r. 32

95. See Barbara Black \& Jill I. Gross, Investor Protection Meets the Federal Arbitration Act, 1 Stan. J. Complex Litig. 1, 49 n.27 (2012).

96. See Arbitration Awards Online, FINRA, http://www.finra.org/arbitrationmediation/arbitration-awards [https://perma.cc/9A57-K2ER] (last visited Apr. 12, 2020).

97. 2268. Requirements When Using Predispute Arbitration Agreements for Customer Accounts, FINRA: RULES \& GUIDANCE (Dec. 5, 2011), https://www.finra.org/rulesguidance/rulebooks/finra-rules/2268 [https://perma.cc/E9GT-E68U] (Rule 2268(d)(3)).

98. 12208. Representation of Parties, FINRA: RULES \& GUIDANCE (Dec. 15, 2008), https://www. finra.org/rules-guidance/rulebooks/finra-rules/12208 [https://perma.cc/J4FHTBCM]. 
year, 99 allows parties to change any procedural rule with consent, 100 requires arbitrators to issue an explained award if all parties request it, 101 and provides a telephonic, oral hearing option for small claims. ${ }^{102}$ A decade ago, I analyzed the fairness of securities arbitration, specifically investors' claims against their brokers, and concluded that it was fair. 103 The forum has only added more fairness features in the decade since. Thus, FINRA arbitration is an arbitration archetype.

\section{CONCLUSION}

The ADR movement was started, in part, because it promised disputants an alternative to the high costs and protracted delays of litigation while ensuring fairer outcomes based not on rigid application of archaic rules but on industry norms and customs. But not all ADR processes achieve this goal. In order to enhance access to justice relative to a court-based process, a dispute resolution process should be efficient, cost-conscious, and accessible and should ensure a fair outcome. Since arbitration processes differ depending on the forum, the industry, and the parties' agreement to arbitrate, it is not possible to conclude whether arbitration in general enhances parties' access to justice. Identifying characteristics of an arbitration process that contribute to access to justice creates a simple framework to locate those subtypes of arbitration that truly deliver on the promise that ADR enhances access to justice. Those "arbitration archetypes" should be used as models for reforms to types of arbitration that do not have the archetypal characteristics - both to improve the fairness of those processes and to put a stop to the overgeneralized nature of arbitration critique. By preserving some types of arbitration and improving others, disputants will continue to believe in the legitimacy of the process and ensure additional access to justice.

99. Dispute Resolution Statistics, FINRA: ARB. \& MEDIATION, https://www.finra.org/ arbitration-mediation/dispute-resolution-statistics\#arbitrationstats [https://perma.cc/G53JGC8W] (last visited Apr. 12. 2020) (reporting an overall turnaround time of 14.1 months for arbitration filings).

100. 12105. Agreement of the Parties, FINRA: Rules \& GUIDANCE (Dec. 15, 2008), https://www.finra.org/rules-guidance/rulebooks/finra-rules/12105 [https://perma.cc/6UB7$7 \mathrm{WKC}]$.

101. 12904. Awards, FINRA: RULES \& GUDANCE (Feb. 21, 2018), https:// www.finra.org/rules-guidance/rulebooks/finra-rules/12904 [https://perma.cc/K6SY-VWRE] (Rule 12904(g)(1)).

102. 12800. Simplified Arbitration, FINRA: RulEs \& GUIDANCE (Sept. 17, 2018), https://www.finra.org/rules-guidance/rulebooks/finra-rules/12800 [https://perma.cc/Y6NDDZRT] (Rule 12800(c)(3)(B)(1)).

103. Jill I. Gross, The End of Mandatory Securities Arbitration?, 30 PACE L. REV. 1174, $1194(2010)$. 